\title{
Chronic Hepatitis C Infection in Children: Current Treatment and New Therapies
}

\author{
Andrew Lee ${ }^{1,2 *}$, Jeremy Rajanayagam ${ }^{1,3}$ and Mona Abdel-Hady ${ }^{1}$ \\ ${ }^{1}$ Birmingham Children's Hospital, Liver Unit, Birmingham, United Kingdom; ${ }^{2}$ The University of Queensland, School of Medicine, \\ Brisbane, Australia; ${ }^{3}$ University of Birmingham, School of Infection and Immunity, Birmingham, United Kingdom
}

\begin{abstract}
Viral hepatitis $C$ is responsible for a large burden of disease worldwide. Treatment of hepatitis C infection is currently undergoing a revolution with the development of new direct acting antivirals that offer higher cure rates and fewer side effects than other medications currently available. Treatment options for children, although well-defined and evidencebased, are limited relative to adults as there are few trials regarding the use of these newly developed agents in children. With so much optimism in the development of novel therapeutic options for hepatitis C, it is timely to review and summarize the current standard of care treatment and indications for treatment of chronic hepatitis $\mathrm{C}$ in children. We provide here an overview of recent drug developments and their potential for use in children.

(c) 2015 The Second Affiliated Hospital of Chongqing Medical University. Published by XIA \& HE Publishing Ltd. All rights reserved.
\end{abstract}

\section{Introduction}

Chronic infection with hepatitis C virus (HCV) carries a significant global health burden in both children and adults, with approximately $3 \%$ of the world's population infected. The prevalence of $\mathrm{HCV}$ in children is estimated to be $0.4 \%$ in the United Kingdom (UK), with a greater than ten-fold rise in prevalence in some developing nations. ${ }^{1,2}$ Vertical, compared to parenteral transmission, is increasingly the major route of acquiring HCV in childhood. Transmission rates from nonhuman immunodeficiency virus (HIV) mothers are reported in around $5 \%$ of cases and account for nearly half of all infected children within the UK. ${ }^{1}$ In contrast, parenteral transmission

Keywords: Hepatitis C; Children; Treatment; Direct acting antivirals; Host targeting agents.

Abbreviations: $\mathrm{BMI}$, body mass index; $\mathrm{CHC}$, chronic hepatitis $\mathrm{C}$; $\mathrm{Cyp}$, cytochrome; DAA, directly acting antivirals; eRVR, extended rapid virologic response; EVR, early viral response; G2/3, genotypes 2 and 3; HCC, hepatocellular carcinoma; HCV, hepatitis C virus; HIV, human immunodeficiency virus; HTA, host targeting antivirals; IFN, interferon; LFTs, liver function tests; NIs, nucleos(t)ide analogue inhibitors; NNPI, non-nucleoside polymerase inhibitors; NS, nonstructural; PEG-IFN- $\alpha$, pegylated interferon- $\alpha$; PEG-IFN-a-2a, Pegasys; PEG-IFN-a-2b, PegIntron; PIs, protease inhibitors; RBV, ribavirin; RNA, ribonucleic acid; RVR, rapid viral response; SOC, standard of care; SVR, sustained viral response; UK, United Kingdom.

Received: 17 November 2014; Revised: 08 December 2014; Accepted: 08 December 2014

DOI: $10.14218 /$ JCTH.2014.00036

* Correspondence to: Andrew Lee, Toowoomba Hospital, Department of Medicine, Pechey St, South Toowoomba, QLD 4350, Australia. Tel: +61746166000, Fax: +61-746166793, E-mail: awl88@outlook.com remains the most common method of infection in the developing world. $^{1,2}$ The overall rate of spontaneous viral clearance following childhood infection is low, with the majority of children developing chronic hepatitis $\mathrm{C}(\mathrm{CHC})$ $(54-86 \%){ }^{2}$ The clinical course of $\mathrm{CHC}$ in children is usually silent, with mildly abnormal liver function tests (LFTs) and minimal inflammation and fibrosis on histology. ${ }^{2-4}$ Nevertheless, fibrosis tends to progress with time, culminating in cirrhosis in $5-10 \%$ or hepatocellular carcinoma (HCC) in $2-5 \%$ in adulthood. 2,3 Thus, continued efforts to effectively treat children and reduce the long-term health and social consequences in pediatric $\mathrm{CHC}$ are justified.

\section{Whom and when to treat}

Children with $\mathrm{CHC}$ are generally asymptomatic, but long-term infection may lead to cirrhosis and HCC over time, and it is recognized that the degree of hepatic fibrosis correlates with age and duration of infection. ${ }^{3}$ The benefits of treating children with $\mathrm{CHC}$ include prevention of disease progression and future complications and elimination of social stigma and caregiver stress. From a population health point of view, treating children with $\mathrm{CHC}$ reduces the global and financial burden of disease that, although not approaching that of adult $\mathrm{CHC}$, is significant. 5

Guidelines recommend interferon (IFN) based treatment after age three; IFN is not recommended under the age of 2 because of the increased chance for spontaneous seroconversion in the first three years of life. ${ }^{6}$

Children with persistently elevated serum aminotransferases or those with progressive fibrosis should be considered for treatment.

Despite these guidelines, questions still remain regarding whom to treat. Uncertainty exists for a number of reasons. Most children with $\mathrm{CHC}$ lack clinical or laboratory evidence of inflammation or progression of disease, although they may benefit from treatment. Even in patients with mild to moderate evidence of disease, the rate of progression to significant fibrosis, cirrhosis, and HCC is slow. The decision to initiate treatment is also impacted by cost, efficacy, and side effects of current treatments, which although proven to be tolerated and effective in certain populations, still have much room for improvement. Furthermore, new treatment options are becoming more readily available for adults, raising the question of whether to wait for approval of these new treatments in children. Experience dictates, however, that it will still be many years before these options are available for children on a non-trial basis. 
Lee A. et al: Current and new treatments of chronic hepatitis $C$ in children

Table 1. Recommended treatment regimen for $\mathrm{CHC}$ in children

\begin{tabular}{llll}
\hline Genotype & Duration (weeks) & \multicolumn{2}{c}{ Regimen } \\
\hline $1 \& 4$ & 48 & Ribavirin $15 \mathrm{mg} / \mathrm{kg} /$ day & PEG-IFN- $\alpha-2 \mathrm{a} 180 \mu \mathrm{g} / 1.73 \mathrm{~m}^{2} /$ week OR \\
$2 \& 3$ & 24 & AND & PEG-IFN- $\alpha-2 \mathrm{~b} 60 \mu \mathrm{g} / \mathrm{m}^{2} /$ week \\
\hline
\end{tabular}

PEG-IFN-a-2a, Pegasys; PEG-IFN-a-2b, PegIntron.

\section{Standard of care treatment}

For children with $\mathrm{CHC}$, the current standard of care (SOC) is to use 24-48 weeks of subcutaneous pegylated interferon- $\alpha$ (PEG-IFN- $\alpha$ ) in combination with oral ribavirin (RBV) (Table 1 ). ${ }^{3}$ IFN- $\alpha$ is a cytokine with a broad mechanism of action that includes increasing antigen presentation of viral peptides, stimulating the activation of CD8+ T-cells and natural killer cells, and inducing the synthesis of several key antiviral protein mediators. ${ }^{7,8}$ The addition of a polyethylene glycol molecule (i.e. PEG-IFN- $\alpha$ ) maintains an active drug with a longer half-life, allowing for weekly dosing, better compliance, and improvement of sustained viral response (SVR, Table 2). PEG-IFN- $\alpha$ is available as a subcutaneous injection, in the forms of PEG-IFN- $\alpha-2$ a (Pegasys; Genentech/ Roche, USA) or PEG-IFN- $\alpha-2 b$ (PegIntron; Merck \& Co, Inc., USA), and no demonstrable difference in efficacy has been established between these forms. ${ }^{3}$ The dose of PEG-IFN- $\alpha-2 a$ is $180 \mu \mathrm{g} / 1.73 \mathrm{~m}^{2}$ weekly, while PEG-IFN- $\alpha-2 \mathrm{~b}$ is $60 \mu \mathrm{g} / \mathrm{m}^{2}$ weekly.

RBV is a guanosine analogue that interferes with $\mathrm{HCV}$ ribonucleic acid (RNA) polymerase, leading to rapid and lethal mutations and intracellular GTP depletion. ${ }^{9-11}$ RBV is available as an orally active agent and RBV in combination with PEG-IFN- $\alpha$ acts synergistically to improve SVR rates, while limiting the development of viral resistance. ${ }^{3,7}$ The dose of RBV is $15 \mathrm{mg} / \mathrm{kg} /$ day, given as two split doses per day.

Duration of therapy depends on HCV genotype, with 24 weeks for genotypes 2 and 3 (G2/3) and 48 weeks for genotypes 1 and 4 (G1/4) (Table 1 ). These recommendations were derived from studies and systematic reviews in noncirrhotic children with $\mathrm{CHC}$. The overall SVR was $30-100 \%$, with improved response rates in G2/3 typically greater than $80 \%$ and in G1/4 predominantly greater than $50 \% .{ }^{12-22}$ Reporting of genotype and rapid viral response (RVR) and early viral response (EVR) (Table 2 ) have been inconsistent among studies, making analysis of these responses difficult. There is limited evidence available regarding the treatment of $\mathrm{CHC}$ in special populations of children, e.g. coinfection with hepatitis B or HIV, post-transplant, and cirrhosis. Hence, in such situations, treatment decisions are based on available data from adult studies. ${ }^{3}$

Although SOC treatment has proven effective, PEG-IFN- $\alpha$ and RBV carry significant side effect profiles, with implications for health, compliance, and quality of life, therefore necessitating close monitoring. ${ }^{23,24}$ Adverse events include flu-like symptoms, bone marrow suppression, hemolytic anemia, growth impairment, and psychiatric symptoms (Table 3). Flu-like symptoms, including fever, headaches, myalgia, and fatigue, occur almost universally in patients within the first few days of treatment but commonly recede by 2 months of therapy. Up to $30 \%$ of patients are reported to have some degree of bone marrow suppression related to PEG-IFN- $\alpha$, typically manifesting as neutropenia and a reduction in total white cell count. ${ }^{16,18}$ The nadir of cell count often occurs following 8 weeks of therapy, and this may prompta dose reduction in PEG-IFN- $\alpha$. Hemolytic anemia is believed to occur consequent to oxidative stress secondary to RBV and often occurs by week four of treatment. ${ }^{24}$ Disruption of growth velocity and loss of weight occur in up to $70 \%$ of patients, and as such treatment is often avoided during anticipated periods of rapid growth. ${ }^{18} \mathrm{~A}$ dose reduction in both RBV and PEG-IFN- $\alpha$ is recommended if a decline of greater than $10 \%$ in weight or body mass index (BMI) is observed. ${ }^{3}$ Neuropsychiatric disturbances are important adverse effects, with most affected patients experiencing agitation or irritability, occasionally low mood, and rarely suicidal ideation or attempts. These disturbances, when present, often instigate cessation of therapy in children. Cutaneous drug reactions are also not uncommon, ranging from injection site reaction, nonspecific erythema, to alopecia. Other less common adverse effects include thyroid abnormalities and ocular complications. ${ }^{24}$

While the experience of using dual therapy offers acceptable efficacy, clinical vigilance is necessary to manage side effects and ensure compliance during prolonged periods of therapy. New antivirals endeavour to provide improved efficacy and reduced side effects, while continuing to limit viral resistance.

\section{New therapies}

Advances in understanding the molecular structure and life cycle of HCV have led to the continued development of novel agents to treat chronic HCV. These agents may be classified into two categories: (1) directly acting antivirals (DAA), which target viral replication directly (Table 4) and (2) host targeting antivirals (HTA), which affect host cell proteins considered paramount to viral replication.

\section{Table 2. Definitions of virologic response}

\begin{tabular}{ll}
\hline Rapid virologic response (RVR) & Undetectable HCV RNA at treatment week 4 \\
Extended rapid virologic response (eRVR) & Undetectable HCV RNA at treatment week 4 and week 12 \\
Early virologic response (partial EVR) & $2 \log _{10}$ reduction in HCV RNA at treatment week 12 \\
Early virologic response (complete EVR) & Undetectable HCV RNA at treatment week 12 \\
Sustained virologic response (SVR) & Undetectable HCV RNA at 24 weeks after initiation of treatment \\
\hline
\end{tabular}

eRVR, extended rapid virologic response; EVR, early viral response; RVR, rapid viral response; SVR, sustained viral response. 
Table 3. Side effects associated with standard of care treatment

\begin{tabular}{ll}
\hline General/constitutional & Arthralgia, myalgia \\
& Fever \\
& Fatigue \\
& Headache \\
& Weight loss \\
& Reduced growth velocity \\
& Anemia \\
Hematological & Thrombocytopenia \\
& Neutropenia \\
& Anorexia \\
Gastrointestinal & Nausea/vomiting \\
& Abdominal pain \\
& Diarrhea \\
& Hyperthyroidism \\
Endocrine & Hypothyroidism \\
& Retinopathy \\
Ophthalmologic & Optic neuropathy/neuritis \\
& Mood change, irritability \\
Neuropsychiatric & Insomnia \\
& Depression \\
& Suicidal ideation \\
& Dermatitis, pruritus \\
& Alopecia \\
Injection site reaction \\
(interferon)
\end{tabular}

\section{Direct acting antivirals}

The first DAAs to be approved for use in the UK for adult patients were the first generation protease inhibitors (PIs) telaprevir and boceprevir. They target the nonstructural (NS) 3 serine protease NS4a cofactor complex required for the cleavage of the HCV genome-encoded polyprotein and implicated in the inactivation of cellular proteins directing host immunity. Both telaprevir and boceprevir offer improved SVR rates for genotype $1 \mathrm{HCV}$ infections when used in triple therapy with PEG-IFN- $\alpha$ and RBV. ${ }^{25-28}$ Studies have reported SVR rates of $67-75 \%$ in treatment naïve patients, and 69$88 \%$ in prior relapsers. SVR rates were not as promising in prior partial-responders and nonresponders, at $40-59 \%$ and 23-38\%, respectively. ${ }^{25-28}$ Their improved efficacy, however, should be leveraged against additional adverse effects; multiple drug interactions; and increased susceptibility to viral resistance. Both PIs are inhibitors of the cytochrome (Сyp) 3A4/5 enzyme and P-glycoprotein transporter, resulting in a large number of interactions with medications, such as antibiotics, analgesics, and anticonvulsants. Boceprevir and telaprevir are associated with anemia, neutropenia, and dysguesia (distortion in taste). Telaprevir is also associated with anorectal discomfort and skin rashes.

A major concern when using these PIs is the early development of viral resistance, which subsequently negates the potential benefit and use of other PIs for a given patient. ${ }^{29,30}$ For this reason, PIs must never be used as mono therapy. A second wave of PIs, such as simeprevir, asunaprevir, and ABT-450 + ritonavir, offer the potential advantages of broader genotype activity, and improved tolerability and resistance profiles. The second wave of PIs are further divided into first and second generation, based on genotypic activity and resistance profiles; second generation PIs offer broader activity and improved barrier to resistance. Simeprevir, a first generation PI with activity against $\mathrm{G} 1 / 4$, was the first available second-wave PI and is used in combination with RBV + PEGIFN-a or sofosbuvir \pm RBV. The second-wave PIs asunaprevir and ABT-450 in combination with ritonavir potentially offer improved adverse effect profiles and barrier to resistance but still have important drug-interactions. The second generation PIs are in various early stages of clinical trials.

Other DAAs at various stages of clinical development include NS5B polymerase inhibitors and NS5A replication complex inhibitors. NS5B polymerase inhibitors restrain RNAdependent RNA polymerase, which is essential for copying the HCV RNA genome and transcribing the mRNA. These agents may be further divided into: (1) nucleos(t)ide analogue inhibitors (NIs), which act as chain terminators by being incorporated into the elongated mRNA at the active site of the enzyme and (2) non-nucleoside polymerase inhibitors (NNPI), a heterogeneous groups of molecules that bind to different enzyme sites, resulting in a conformational protein change before the elongation complex is formed.

Sofosbuvir was the first available NI and is used with PEGIFN- $\alpha$ for $\mathrm{G} 1 / 4$, with simeprevir \pm RBV for genotype 1 , or with RBV for G2/3. Sofosbuvir is well tolerated, associated with a low probability of drug resistance, and has less drug interactions than PIs. These DAAs have been evaluated in numerous phase 3 trials in various combinations as interferon free regimens with promising results. ${ }^{31-41}$ The various regimens of sofosbuvir and/or simeprevir \pm RBV demonstrate approximately $80-90 \%$ SVRs at 12 weeks treatment duration with minimal additional benefit of 24 weeks in treatment naïve genotype 1 patients. Sofosbuvir in combination with RBV has demonstrated $\sim 90 \%$ SVR with 12 weeks of treatment in genotype $2 .{ }^{35,37,40}$ Results for the same regimen in genotype 3 show $27-62 \%$ SVR at 12 weeks and $85 \%$ at 24 weeks, illustrating the requirement for longer treatment duration in genotype 3 with this regimen. ${ }^{35,37,40}$ A phase 2 trial of sofosbuvir + RBV for G2/3 infection in children is currently recruiting participants. ${ }^{42}$ In contrast to NIs, NNPIs are not as effective across all HCV genotypes. NNPIs such as setrobuvir are currently being evaluated in early phase adult trials.

NS5a inhibitors act on the NS5a protein that is required in the regulation and organization of HCV replication, assembly, and release. Daclatasvir, Ombitasvir (ABT-267), and ledipasvir are NS5A inhibitors currently in early phase trials. These promise to be effective against all genotypes but may be limited by their low barrier to resistance. A phase II trial examining the combination treatment of ledipasvir/sofosbuvir (Harvoni, USA) for children is registered to confirm safety and determine age-appropriate dosing but recruitment for the study has not yet commenced. ${ }^{43}$

Other agents targeting HCV that are in early stages of trials include agents developed against the NS4b protein involved in assembly of the replication complex as well as the p7 ion channel and structural core protein important for assembly of the virus. ${ }^{44-47}$

\section{Host targeting antivirals and newer analogues}

Agents that act on the host immune system targets (e.g. Cyclophilin A protein, miR122 micro RNA) to interfere with viral replication are also in various stages of development. ${ }^{48-51}$ 
Lee A. et al: Current and new treatments of chronic hepatitis $C$ in children

Table 4. DAA Targets

\begin{tabular}{|c|c|c|c|c|c|c|}
\hline Target & Role & Class & Examples & Manufacturer & $\begin{array}{l}\text { Genotype } \\
\text { coverage }\end{array}$ & $\begin{array}{l}\text { Barrier to } \\
\text { resistance }\end{array}$ \\
\hline \multirow[t]{9}{*}{$\mathrm{NS3} / 4 \mathrm{a}$} & Serine protease & $1^{\text {st }}$ generation ( $1^{\text {st }}$ wave) & Boceprevir & Merck & Narrow & Low \\
\hline & & & Telaprevir & Vertex, Janssen & & \\
\hline & & $1^{\text {st }}$ generation ( $2^{\text {nd }}$ wave) & Simeprevir* & Janssen & Narrow & Low \\
\hline & & & Asunaprevir & $\begin{array}{l}\text { Bristol-Myers } \\
\text { Squibb }\end{array}$ & & \\
\hline & & & Faldaprevir & $\begin{array}{l}\text { Boehringer- } \\
\text { Ingelheim }\end{array}$ & & \\
\hline & & & ABT -450 & Abbvie & & \\
\hline & & & Paritaprevir & & & \\
\hline & & $2^{\text {nd }}$ generation & MK-5172 & Merck & Broad & Medium \\
\hline & & & $\mathrm{ACH}-2684$ & Achillion & & \\
\hline \multirow[t]{6}{*}{ NS5a } & $\begin{array}{l}\text { Protein involved } \\
\text { in replication }\end{array}$ & $1^{\text {st }}$ generation & Daclatasvir & $\begin{array}{l}\text { Bristol-Myers } \\
\text { Squibb }\end{array}$ & Medium-Broad & Low \\
\hline & & & Ombitasvir & Abbvie & & \\
\hline & & & Ledipasvir & Gilead & & \\
\hline & & $2^{\text {nd }}$ generation & MK8742 & Merck & Broad & Medium \\
\hline & & & $\mathrm{ACH}-3102$ & Achillion & & \\
\hline & & & GS-5816 & Gilead & & \\
\hline \multirow[t]{4}{*}{ NS5b } & $\begin{array}{l}\text { RNA dependent } \\
\text { RNA polymerase }\end{array}$ & Nucleoside & Sofosbuvir & Gilead & Broad & High \\
\hline & & & $V X-135$ & Vertex & & \\
\hline & & Non-nucleoside & Dasabuvir & Abbvie & Narrow & Low \\
\hline & & & Setrobuvir & Roche & & \\
\hline
\end{tabular}

*currently available.

NS, nonstructural.

CyclophilinA is a peptidyl-prolylcis-trans isomerase that is inhibited by the immunosuppressant Cyclosporin A. Nonimmunosuppressive Cyclophilin inhibitors, such as alisporivir, have been developed following observations that Cyclosporin A effectively suppresses HCV replication.

miR122, another promising host target, is a liver specific micro RNA postulated to stabilize and protect HCV RNA from degradation, stimulate translation, and enhance replication. The miR122-targeting anti-sense oligonucleotide miravirsen has demonstrated antiviral activity in clinical trials. However, there are some concerns regarding its role in inhibition of lipid metabolism and tumor suppression.

\section{Discussion}

The standard treatment of $\mathrm{CHC}$ in children remains combination therapy of PEG-IFN + RBV. The introduction of new DAA regimens represents a new era of HCV treatment. Current literature regarding treatment of $\mathrm{CHC}$ in children demonstrates efficacy of SOC treatment against HCV that is well tolerated. ${ }^{3,14}$ The differential SVR rates between genotypes, as discussed previously, highlight the necessity of therapies with improved efficacy against genotype 1 . In adults, DAAs in the form of first generation PIs met this niche at the cost of additional side effects.

New DAAs and HTAs offer greater efficacy, broader genotypic activity, increased barrier to resistance, and improved adverse effect profiles. The data in adults promise SVRs $>90 \%$ with 12 weeks of treatment in certain populations and genotypes. The drug interactions of first generation PIs remain less than ideal, although other DAAs have fewer interactions. Barrier to viral resistance appears to be improved in simeprevir and in the NS5b NPI sofosbuvir. Evidence supporting IFN-free and even RBV-free regimens represents significant steps toward reducing side effects in treatment of $\mathrm{CHC}$, as it avoids the side effects associated with SOC treatment.

While treatment options for $\mathrm{CHC}$ in adults are set to increase rapidly in the next few years, $\mathrm{CHC}$ in children will remain part of the global burden of HCV until equally effective treatment options have demonstrated efficacy and safety in children. The paucity of pharmacokinetic, efficacy, and safety data in children is one of three issues in treatment of $\mathrm{CHC}$ in children. ${ }^{3,52} \mathrm{~A}$ second issue is the lack of consensus regarding which patients and when to treat, which is an issue that is likely to remain even after the first is resolved. ${ }^{3}$ The lack of data and lack of consensus on whom to treat are inter-related problems because without a defined treatment population it is difficult to design a robust trial. The third issue is common to both adults and children and relates to access to resources and cost of these treatments. Even in developed countries, the cost of RBV, PEG-IFN, and in particular DAAs is significant, and in developing countries, the costs are often prohibitive in the treatment of $\mathrm{CHC} .53,54$

In the treatment of $\mathrm{CHC}$ in children, it is likely that regimens using these DAAs will become the treatments of choice for patients who have access to them. This relies on the design of robust trials in order to provide evidence of effective, safe regimens that can be used in well-defined groups of children with $\mathrm{CHC}$. 


\section{Conclusions}

Trials of DAAs in children will provide a greater range of evidence-based treatment options with improved efficacy and side effect profiles. Until this evidence and experience is obtained, SOC treatment is well tolerated and the benefits can outweigh the side effects in many children with chronic hepatitis $\mathrm{C}$.

\section{Conflict of interest}

None

\section{Author contributions}

Drafting and revising the manuscript $(A L)$, providing critical revision (JR, MAH).

\section{References}

[1] Mohd Hanafiah K, Groeger J, Flaxman AD, Wiersma ST. Global epidemiology of hepatitis $C$ virus infection: new estimates of age-specific antibody to HCV seroprevalence. Hepatology 2013;57:1333-1342. doi: 10.1002/hep.26141.

[2] El-Shabrawi MH, Kamal NM. Burden of pediatric hepatitis C. World J Gastroenterol 2013;19:7880-7888. doi: 10.3748/wjg.v19.i44.7880.

[3] Mack CL, Gonzalez-Peralta RP, Gupta N, Leung D, Narkewicz MR, Roberts EA, et al. NASPGHAN practice guidelines: Diagnosis and management of hepatitis C infection in infants, children, and adolescents. J Pediatr Gastroenterol Nutr 2012;54:838-855. doi: 10.1097/MPG.0b013e3182583 28d.

[4] Indolfi G, Bartolini E, Casavola D, Resti M. Chronic hepatitis C virus infection in children and adolescents: Epidemiology, natural history, and assessment of the safety and efficacy of combination therapy. Adolesc Health Med Ther 2010;1:115-128. doi: 10.2147/AHMT.S6750.

[5] Jhaveri R, Grant W, Kauf TL, McHutchison J. The burden of hepatitis C virus infection in children: estimated direct medical costs over a 10 -year period. J Pediatr 2006;148:353-358. doi: 10.1016/j.jpeds.2005.10.031.

[6] Davison SM, Mieli-Vergani G, Sira J, Kelly DA. Perinatal hepatitis C virus infection: diagnosis and management. Arch Dis Child 2006;91:781-785. doi: 10.1136/adc.2005.081877.

[7] Feld JJ, Hoofnagle JH. Mechanism of action of interferon and ribavirin in treatment of hepatitis C. Nature 2005;436:967-972. doi: 10.1038/nature 04082.

[8] Guo JT, Sohn JA, Zhu Q, Seeger C. Mechanism of the interferon alpha response against hepatitis $C$ virus replicons. Virology 2004;325:71-81. doi: 10.1016/j.virol.2004.04.031.

[9] Thomas E, Ghany MG, Liang TJ. The application and mechanism of action of ribavirin in therapy of hepatitis C. Antivir Chem Chemother 2013;23:1-12. doi: 10.3851/IMP2125

[10] Crotty S, Maag D, Arnold JJ, Zhong W, Lau JY, Hong Z, et al. The broadspectrum antiviral ribonucleoside ribavirin is an RNA virus mutagen. Nat Med 2000;6:1375-1379. doi: 10.1038/82191.

[11] Lau JY, Tam RC, Liang TJ, Hong Z. Mechanism of action of ribavirin in the combination treatment of chronic HCV infection. Hepatology 2002;35:10021009. doi: 10.1053/jhep.2002.32672.

[12] Abdel-Hady M, Bansal S, Davison SM, Brown M, Tizzard SA, Mulla S, et al. Treatment of chronic viral hepatitis $C$ in children and adolescents: UK experience. Arch Dis Child 2014;99:505-510. doi: 10.1136/archdischild2013-304601.

[13] Al Ali J, Owayed S, Al-Qabandi W, Husain K, Hasan F. Pegylated interferon alfa-2b plus ribavirin for the treatment of chronic hepatitis $C$ genotype 4 in adolescents. Ann Hepatol 2010;9:156-160.

[14] Jara P, Hierro L, de la Vega A, Díaz C, Camarena C, Frauca E, et al. Efficacy and safety of peginterferon-alpha2b and ribavirin combination therapy in children with chronic hepatitis C infection. Pediatr Infect Dis J 2008;27:142148. doi: 10.1097/INF.0b013e318159836c.

[15] Pawlowska M, Pilarczyk M, Halota W. Virologic response to treatment with Pegylated Interferon alfa-2b and Ribavirin for chronic hepatitis $\mathrm{C}$ in children. Med Sci Monit 2010;16:CR616-CR621.

[16] Schwarz KB, Gonzalez-Peralta RP, Murray KF, Molleston JP, Haber BA, Jonas $\mathrm{MM}$, et al. The combination of ribavirin and peginterferon is superior to peginterferon and placebo for children and adolescents with chronic hepatitis C. Gastroenterology 2011;140:450-458.e1. doi: 10.1053/j.gastro.2010.10.047.

[17] Sokal EM, Bourgois A, Stephenne X, Silveira T, Porta G, Gardovska D, et al. Peginterferon alfa-2a plus ribavirin for chronic hepatitis $C$ virus infection in children and adolescents. J Hepatol 2010;52:827-831. doi: 10.1016/ j.jhep.2010.01.028.

[18] Wirth S, Pieper-Boustani H, Lang T, Ballauff A, Kullmer U, Gerner P, et al. Peginterferon alfa-2b plus ribavirin treatment in children and adolescents with chronic hepatitis C. Hepatology 2005;41:1013-1018. doi: 10.1002/ hep. 20661

[19] Wirth S, Ribes-Koninckx C, Calzado MA, Bortolotti F, Zancan L, Jara P, et al. High sustained virologic response rates in children with chronic hepatitis $C$ receiving peginterferon alfa-2b plus ribavirin. J Hepatol 2010;52:501-517. doi: $10.1016 / j$.jhep.2010.01.016.

[20] Zhang HF, Yang X], Zhu SS, Dong Y, Chen DW, Jia WZ, et al. [An open-label pilot study evaluating the efficacy and safety of peginterferon alfa-2a combined with ribavirin in children with chronic hepatitis C]. Zhonghua Shi Yan He Lin Chuang Bing Du Xue Za Zhi 2005;19:185-187.

[21] Druyts E, Thorlund K, Wu P, Kanters S, Yaya S, Cooper CL, et al. Efficacy and safety of pegylated interferon alfa-2a or alfa-2b plus ribavirin for the treatment of chronic hepatitis $C$ in children and adolescents: a systematic review and meta-analysis. Clin Infect Dis 2013;56:961-967. doi: 10.1093/ $\mathrm{cid} / \mathrm{cis} 1031$.

[22] Hu J, Doucette K, Hartling L, Tjosvold L, Robinson J. Treatment of hepatitis C in children: a systematic review. PloS one 2010;5:e11542. doi: 10.1371 /journal.pone.0011542.

[23] Foster GR. Quality of life considerations for patients with chronic hepatitis C. J Viral Hepat 2009;16:605-611. doi: 10.1111/j.1365-2893.2009.01154.x.

[24] Sung H, Chang M, Saab S. Management of Hepatitis C Antiviral Therapy Adverse Effects. Curr Hepat Rep 2011;10:33-40. doi: 10.1007/s11901010-0078-7.

[25] Bacon BR, Gordon SC, Lawitz E, Marcellin P, Vierling JM, Zeuzem S, et al. Boceprevir for previously treated chronic HCV genotype 1 infection. N Engl J Med 2011;364:1207-1217. doi: 10.1056/NEJMoa1009482.

[26] Jacobson IM, McHutchison JG, Dusheiko G, Di Bisceglie AM, Reddy KR, Bzowej $\mathrm{NH}$, et al. Telaprevir for previously untreated chronic hepatitis $\mathrm{C}$ virus infection. N Engl J Med 2011;364:2405-2416. doi: 10.1056/NEJMoa1012912.

[27] Poordad F, McCone J Jr, Bacon BR, Bruno S, Manns MP, Sulkowski MS, et al. Boceprevir for untreated chronic HCV genotype 1 infection. N Engl J Med 2011;364:1195-1206. doi: 10.1056/NEJMoa1010494.

[28] Zeuzem S, Andreone P, Pol S, Lawitz E, Diago M, Roberts S, et al. Telaprevir for retreatment of HCV infection. N Engl J Med 2011;364:2417-2428. doi: 10.1056/NEJMoa1013086.

[29] Sarrazin C, Kieffer TL, Bartels D, Hanzelka B, Müh U, Welker M, et al. Dynamic hepatitis $C$ virus genotypic and phenotypic changes in patients treated with the protease inhibitor telaprevir. Gastroenterology 2007;132: 1767-1777. doi: 10.1053/j.gastro.2007.02.037.

[30] Susser S, Welsch C, Wang Y, Zettler M, Domingues FS, Karey U, et al. Characterization of resistance to the protease inhibitor boceprevir in hepatitis C virus-infected patients. Hepatology 2009;50:1709-1718. doi: 10.1002/hep.23192.

[31] Afdhal N, Reddy KR, Nelson DR, Lawitz E, Gordon SC, Schiff E, et al. Ledipasvir and sofosbuvir for previously treated HCV genotype 1 infection. N Engl J Med 2014;370:1483-1493. doi: 10.1056/NEJMoa1316366.

[32] Afdhal N, Zeuzem S, Kwo P, Chojkier M, Gitlin N, Puoti M, et al. Ledipasvir and sofosbuvir for untreated HCV genotype 1 infection. N Engl J Med 2014;370: 1889-1898. doi: 10.1056/NEJMoa1402454.

[33] Feld J], Kowdley KV, Coakley E, Sigal S, Nelson DR, Crawford D, et al. Treatment of $\mathrm{HCV}$ with $\mathrm{ABT}-450 / \mathrm{r}$-ombitasvir and dasabuvir with ribavirin. N Engl J Med 2014;370:1594-1603. doi: 10.1056/NEJMoa1315722.

[34] Ferenci P, Bernstein D, Lalezari J, Cohen D, Luo Y, Cooper C, et al. ABT-450/rombitasvir and dasabuvir with or without ribavirin for HCV. N Engl J Med 2014;370:1983-1992. doi: 10.1056/NEJMoa1402338.

[35] Jacobson IM, Gordon SC, Kowdley KV, Yoshida EM, Rodriguez-Torres M, Sulkowski MS, et al. Sofosbuvir for hepatitis C genotype 2 or 3 in patients without treatment options. N Engl J Med 2013;368:1867-1877. doi: 10.1056/NEJMoa1214854.

[36] Kowdley KV, Gordon SC, Reddy KR, Rossaro L, Bernstein DE, Lawitz E, et al. Ledipasvir and sofosbuvir for 8 or 12 weeks for chronic HCV without cirrhosis. N Engl J Med 2014;370:1879-1888. doi: 10.1056/NEJMoa1402355.

[37] Lawitz E, Mangia A, Wyles D, Rodriguez-Torres M, Hassanein T, Gordon SC, et al. Sofosbuvir for previously untreated chronic hepatitis $C$ infection. N Engl J Med 2013;368:1878-1887. doi: 10.1056/NEJMoa1214853.

[38] Manns M, Pol S, Jacobson I. All-oral dual therapy with daclatasvir and asunaprevir in patients with HCV genotype 1B infection: phase 3 study results. J Hepatol 2014;60:S524-S525. doi: 10.1016/S0168-8278(14) 61461-6.

[39] Poordad F, Hezode C, Trinh R, Kowdley KV, Zeuzem S, Agarwal K, et al. ABT$450 /$ r-ombitasvir and dasabuvir with ribavirin for hepatitis $C$ with cirrhosis. N Engl J Med 2014;370:1973-1982. doi: 10.1056/NEJMoa1402869. 
Lee A. et al: Current and new treatments of chronic hepatitis $C$ in children

[40] Zeuzem S, Dusheiko GM, Salupere R, Mangia A, Flisiak R, Hyland RH, et al. Sofosbuvir and ribavirin in HCV genotypes 2 and 3. N Engl J Med 2014;370: 1993-2001. doi: 10.1056/NEJMoa1316145.

[41] Zeuzem S, Jacobson IM, Baykal T, Marinho RT, Poordad F, Bourlière M, et al. Retreatment of HCV with ABT-450/r-ombitasvir and dasabuvir with ribavirin. N Engl J Med 2014;370:1604-1614. doi: 10.1056/NEJMoa1401561.

[42] http://clinicaltrials.gov/ct2/show/NCT02175758, accessed June 2014.

[43] http://clinicaltrials.gov/ct2/show/NCT02249182, accessed September 2014.

[44] Cho NJ, Dvory-Sobol H, Lee C, Cho SJ, Bryson P, Masek M, et al. Identification of a class of HCV inhibitors directed against the nonstructural protein NS4B. Sci Transl Med 2010;2:15ra6. doi: 10.1126/scitranslmed.3000331.

[45] Einav S, Gerber D, Bryson PD, Sklan EH, Elazar M, MaerkI SJ, et al. Discovery of a hepatitis $C$ target and its pharmacological inhibitors by microfluidic affinity analysis. Nat Biotechnol 2008;26:1019-1027. doi: 10.1038/nbt.1490.

[46] Ni F, Kota S, Takahashi V, Strosberg AD, Snyder JK. Potent inhibitors of hepatitis $C$ core dimerization as new leads for anti-hepatitis $C$ agents. Bioorg Med Chem Lett 2011;21:2198-2202. doi: 10.1016/j.bmcl.2011.03.014.

[47] Pavlovic D, Neville DC, Argaud O, Blumberg B, Dwek RA, Fischer WB, et al. The hepatitis $C$ virus $\mathrm{p} 7$ protein forms an ion channel that is inhibited by longalkyl-chain iminosugar derivatives. Proc Natl Acad Sci USA 2003;100:61046108. doi: $10.1073 /$ pnas. 1031527100
[48] Flisiak R, Feinman SV, Jablkowski M, Horban A, Kryczka W, Pawlowska M, et al. The cyclophilin inhibitor Debio 025 combined with PEG IFNalpha2a significantly reduces viral load in treatment-naive hepatitis $\mathrm{C}$ patients. Hepatology 2009;49:1460-1468. doi: 10.1002/hep.22835.

[49] Janssen HL, Reesink HW, Lawitz EJ, Zeuzem S, Rodriguez-Torres M, Patel K, et al. Treatment of HCV infection by targeting microRNA. N Engl J Med 2013; 368:1685-1694. doi: 10.1056/NEJMoa1209026.

[50] Jopling CL, Yi M, Lancaster AM, Lemon SM, Sarnow P. Modulation of hepatitis C virus RNA abundance by a liver-specific MicroRNA. Science 2005;309: 1577-1581. doi: 10.1126/science.1113329.

[51] Lanford RE, Hildebrandt-Eriksen ES, Petri A, Persson R, Lindow M, Munk ME, et al. Therapeutic silencing of microRNA-122 in primates with chronic hepatitis C virus infection. Science 2010;327:198-201. doi: 10.1126/ science. 1178178

[52] Vajro P, Veropalumbo C, Maddaluno S, Salerno M, Parenti G, Pignata C. Treatment of children with chronic viral hepatitis: what is available and what is in store. World J Pediatr 2013;9:212-220. doi: 10.1007/s12519-0130426-0.

[53] Jayasekera CR, Barry M, Roberts LR, Nguyen MH. Treating hepatitis C in lower-income countries. N Engl J Med 2014;370:1869-1871. doi: 10.1056/ NEJMp1400160.

[54] Hoofnagle JH, Sherker AH. Therapy for hepatitis C-the costs of success. N Engl J Med 2014;370:1552-1553. doi: 10.1056/NEJMe1401508. 